\title{
The Forced Destiny of Hijra Community: A Critique of Dattani's Play Seven Steps Around the Fire
}

\author{
Dr. Ebrahim Sk
}

Ph.D., English, AMU, Aligarh, UP, India

\begin{abstract}
English playwrights in India are deeply concerned about various social, political and cultural ills and maladies of Indian society. Among them Mahesh Dattani is the most serious contemporary playwrights. His major study areas are social realities and sensational issues like unusual love relationship, same-sex relationship, women exploitation and child-sex abuse, sexuality and gender discrimination. The play Seven Steps Around the Fire highlights the plight of hijra community of Indian society. It alarms socio-psychological crisis, conflict, anguish, fear, frustration and humiliation of the hijra community that is forced on them by the so-called respected society. It questions the age-old belief of marriage being based on heterosexual relationship. Present paper focusses social prejudices, discrimination and abuse against the hijra community.
\end{abstract}

Keywords_-Maladies, social realities, sexuality, gender discrimination and heterosexual.

English playwrights in India - Vijay Tendulkar, Girish Karnad, Mohan Rakesh and Badal Sarkar- are deeply concerned about various social, political and cultural ills and maladies of Indian society. Mahesh Dattani is the most serious contemporary playwrights. Like G B Shaw and Henry Ibsen, his plays deal with the burning social and political problems. His major study areas are social realities and sensational issues like unusual love relationship, samesex relationship, women exploitation and child-sex abuse, sexuality and gender discrimination. He is a successful stage director and playwright in India and abroad who won prestigious Sahitya Academy Award for his Final Solution and Other Plays in 1998. His other significant plays are Seven Steps Around the Fire, On a Muggy Night in Mumbai, Do the Needful, Bravely Fought the Queen, and most famous Tara.

The play Seven Steps Around the Firewas broadcast on BBC Radio 4, on January 9, 1999 as Seven Circles Around the Fire and was first performed on stage at Museum Theatre, Chennai, by MTC Production \& The Madras Players on 6 August 1999. Dattani in this play highlights the plight of hijra community of Indian society. The hijra community is most vulnerable and backward community in India socially, economically and politically. They are deprived of several rights under the civil law because Indian law does not recognize neutral gender. They are thrown into an isolated and dark world and constituted an 'invisible minority' in the society. It was believed that their curse couldn't be revoked because they are 'chosen of god'.

The Indian Constitution affirmed that every person is equal before the law and there shall be no discrimination on the basis of religion, caste, class, sex, gender and place of birth. But we find social exclusion and inclination base biases on the ground of caste, class and religion. For hijra community, this discrimination is based on their neutral gender.More than one million Indian hijra live in an unhygienic condition struggling with extreme penury and internal disharmony. They are no acceptable in the society as a 'normal being'. Most members of the community are those who have removed their genitals through castration, usually without consent. They sometime believed that their ambiguous sexuality is a result of fate and trace their destiny; but forced castration is a sheer violation of individual human right.

The Seven Steps Around the Fire dismays sociopsychological crisis, conflict, anguish, fear, frustration and humiliation of the hijra community that is forced on them by 
the so-called respected society. About the theme of the play Dr. Beena Agarwal remarks,

Dattani in the process of engineering the current of Indian drama by bringing it closer to the real-life experiences tried to articulate the voice of the oppressed sections of the society whose identity is shrouded in the cover of myths and social prejudices. They have been dragged in darkness, doomed to survive in perpetual silence bearing the oppressive burden of hegemony of the elitist class. Dattani within the framework of dramatic structure tries to investigate the identities of those who occupy no space in social order. (34)

The hijra community has been the integral part of Indian society since time immemorial. They were prized as guards of harems, and as companions, by kings and emperor. They possessed good military record during the Sultanate and the Mughal Empire. In the first 'voice-over', Uma clears many doubts regarding the hijras and their social positioning:

Case 7. A brief note on the popular myths on the origin of the hijras will be in order, before looking at the class-gender-based power implications. The term hijra, of course, is of Urdu origin, a combination of Hindi, Persian and Arabic, literally meaning 'neither male nor female'. Another legend traces their ancestry to the Ramayana. The legend has it that god Rama was going to cross the river and go into exile in the forest. All the people of the city wanted to follow him. He said, 'Men and women, turn back.' Some of his male followers did not know what to do. They could not disobey him. So they sacrificed their masculinity, to become neither men nor women, and followed him to the forest. Rama was pleased with their devotion and blessed them. There are transsexuals all over the world, and India is no exception. The purpose of this case study is to show their position in society. Perceived as the lowest of the low, they yearn for family and love. The two events in mainstream Hindu culture where their presence is acceptable marriage and birth - ironically are the very same privileges denied to them by man and nature.

Not for them the seven rounds witnessed by the fire god, eternally binding man and woman in matrimony, or the blessings of 'May you be the mother of a hundred sons.(Collected Plays, 10-11)
There are social prejudices, discrimination and abuse against the hijra community. These prejudices translated into violence, often brutal, in public spaces, police station, prisons, and even in their home. Uma, heroin of the play, belongs to a reputed section of the society who is writing her thesis on class-gender- based power implications. She is a model for those women who wish to establish their individual identity in the male dominated society. Instead of any conventional cases of domestic violence and dowry deaths, she is interested in a hijra (Kamala) murder case for which one of the hijra of her community, Anarkali, has been arrested. Munswamy insisted Uma not to take the case about the hijras. He thought that they are "worthless pig' which will 'bring shame' to her family. In the jail Uma meets Anakali and asked about Kamla's death. Uma after her meeting with Anarkali, decides to visit Champa, the head hijra and ponders over the nature of hijra community and their isolation. Uma thought,

Nobody seems to know anything about them. Neither do they. Did they come to this country with Islam, or are they a part of our glorious Hindu tradition? Why are they so obsessed with weddings and ceremonies of childbirth? How do they come to know of these weddings? Why do they just show up without being invited? Are they just extortionists? And why do they not take singing lessons?(Collected Plays, 16)

InSeven Steps Around the FireDattani is questioning the ageold belief of marriage being based on heterosexual relationship. He seems to say that as heterosexual relationship is natural so the homosexual and lesbian relationship and this should be permitted in India.The lowerclass background and ambiguous sexuality make the hijras on of the most disempowered community in the society. They are allowed "two events in mainstream Hindu culture where their presence is acceptable- marriage and childbirth." A hijra named Kamala was secretly married to Subbu, the son of a Minister. She (Kamla) was burned to death at the behest of the Minister who hastily arranged a girl for marriage to his son. But at the wedding ceremony, which was attended by guests as well as hijras, Subbu brought out a gun and shot at himself. The suicide was hushed up. The story of the love affair between Kamala and Subbu shows the impossibility of the marriage between a eunuch and a man in Indian society.

The hijras areone of the major 'subaltern' marginalized communities in the Indian society like homosexuals, lesbians 
and women. They are forced to maintain silence against oppression and injustice. In the essay "Can the Subaltern Speak?" by 'subaltern' Spivak means the oppressed subjects or more generally those 'of inferior rank'. She anguished that 'subaltern' has no history and cannot speak deeply in shadow. She said that the communications that take place between the subaltern and non-subaltern is actually lost due to element of noise. The element of noise is influenced by racial, cultural and socio-economic factors. Another problem of subaltern, as Spivak opinioned, that their words cannot be properly interpreted. Dattani's play Seven Steps Around the Fire represents the voice of hijra community who are not even allowed to show their faces in society. The play deals with the violence inflicted on the hijras, who are unseen and unheard in the society. They become an 'invisible minority' and "they only come out in groups and make their presence felt by their peculiar loud hand clap."Uma very beautifully remarks their condition and comments:

Anarkali, Champa and all the hijra people knew who was behind the killing of Kamla. They have no voice. The case was hushed up and was not even reported in the newspaper. Champa was right. The police made no arrest. Subbu's suicide was written off as an accident. The photograph was destroyed. So were the lives of two young people.... (Collected Plays, 42)

Dattani'sSeven Steps Around the Firerevolves around the existential problem of the 'third gender', the community of eunuchs, their existence on the fringes of the Indian milieu. They inhabit at the tiny pockets of Indian cities and tread areas that are generally brushed aside to the fringes, the margins of society, as it were. This is literally a no man's land in many senses of the term, and no woman's either. Violence is widespread and everyday reality for the hijras. Public places and even police station they are often harassed and abused physically and sexually. This can be understood as a punishment for not conforming to the gender roles laid by the society. The media have also reinforced stereotype about hijras. Even progressive and anti-establishment publication describe hijras as a race apart, freaks of the underground, half-man half-women, almost devilish in their customs and practices. While investigating the murder of Kalma, Uma said that there is little written about the hijra community in the history. Their witness is not granted as true in the Police Station, even in the court too. They are labeled as 'liar' who fought like 'dogs' every day. This puzzled Uma to think about the position and treatment of hijras in the society.

Karl Marx viewed that there was class struggle in the history of human evaluation, establishing one class himself over the subordinate class for economic, social and political advantage. At present era they become dominant and exploitative class, who are the owners of the means of production and distribution. The subordinate class becomes wage-earning working class. The subordinate class is further divided in different sub groups. The lower group is brutally abused and subjugated and suppressed by the dominant class. The play Seven Steps Around the Fire highlights the brutality and cruel treatment of our cops to the hijra community. Suresh, the Police superintendent, doesn't have any sympathy for the eunuch and advises her wife not to develop good relationship with Anarkali. He calls them liar and "castrated degenerate men". Anarkali is hopeless and frustrated. The helplessness of Anarkali is highlighted in the following dialogues:

"Uma: You can't do that! You have to report to the police station.

Anarkali: They will kill me also if I tell the truth. If I don't tell the truth, I will die in jail."

Mr. Sharma, the local MLA, is exploitative and evil in nature. His son, Subbu falls in love with Kamla, a hijra, and marries her but with the help of Salim Mr. Sharma burn Kamla into death. Hehides all the evidences and makes his son to marry another'normal' girl. The corrupt behavior of authority also expressed in the curse of Champa, guru of the hijras: "If I have money, I would throw it on that superintendent's face and get her (Anarkali) back. Sons of whores, all of them." The injustice against the hijra community results death of Kamla, who just wanted to start new life with Subbu. Subbu killed himself in the ceremony of his second marriage. Subbu, seeing dancing Anarkali, recalls the image of diseased Kamla. He becomes restless and fanatic. He snatches Suresh's gun and cries out "you killed her", and "I am leaving you all! You can't keep me away from Kamla." But like other injustice, the case was not even reported in the newspapers next day.

Dattani shares intense concerns for the marginalized groups of the society in his writings, be they women, children, homosexuals or hijras. He admitted, "I'm strongly affected by social issues, especially when it comes to power play in class and gender. A lot of my plays deal with them and they remain the leitmotifs of my plays." Though Uma belongs to 
the upper echelons of the society, the play Seven Steps Around the Fire shows hijra and women are not treated so very differently. It reminds us about the worldwidemovement of women for cultural, social, legal rights and right for equality.Virginia Woolf in her essay A Room of One's Own(1929) said that the "patriarchal' society hindered and prevented women from realizing their cultural, economic, educational productive and creative abilities. It is the malecentered society that controls all the aspects of women world. Women become 'others' in the society, forced by the male dominated chauvinistic society.

Simone de Beauvoir remarks, "One is not born, but rather becomes, a woman.... It is civilization as whole that produces this creature... which is described as feminine." (TheSecond Sex, 35)Uma is an independent woman in the male dominated patriarchal society. Her position as the wife of the Superintendent and daughter-in-law of the Deputy Commissioner gives her easy access to the prison where Anarkali, a hijra, has been imprisoned for the murder of her 'sister' Kamala, a fellow hijra. Uma shows her strong attitude and strength will at the prison, at Champa's house, at Mr. Sharma's home or at Subbu's wedding ceremony. And yet, for all her privileged background, her scholarly pursuits, or even her attempt at playing detective, Uma is a powerless individual, particularly disadvantaged as a 'barren' woman.She submits to Suresh's whims, lets herself be treated as a sex object, and does little to resist his attempts to control every aspect of her life, including deciding what lingerie she should wear to please him. She is labeled as childless barren womanlike Anarkali who is confused about her 'gender'. Uma's status as an educated woman from a privileged socio-economic class cannot prevent her from being treated much the same as a 'hijra'. So, Uma is perhaps far more marginalized than the hijras.

To conclude, it can be said that Dattani'sSeven Steps Around the Fire deals with a pathetic controversial topic without offering any suitable solution. One hand it brings out our attention about the plight of hijra community, on the other exposes the subaltern and subordinate position of females. This divides the Indian society in to two poles i.e. 'center' and 'margin'. The marginalized voice is suppressed by the established order that prevails in the society. The play also raises many questions regarding hijra identity, their constitution, connotations, their social acceptability and tolerability. India is now one of the global powers in the world, economically and technologically, but the fears and frustrations of hijras are still increasing. There was a ray of hope for this community when Manabi Banerjee became the first transgender principal in India. But her resignation from the post once again reflects the common men negative attitude towards them. Recent Supreme Court order about the rights of transgender brings solace in the heart and mind of this community. In a landmark judgement in 2014, the Supreme Court observed, "In view of the constitutional guarantee, the transgender community is entitled to basic rights i.e. Right to Personal Liberty, dignity, Freedom of expression, Right to Education and Empowerment, Right against violence, Discrimination and exploitation and Right to work. Moreover, every person must have the right to decide his/her gender expression and identity, including transsexuals, transgender, hijras and should have right to freely express their gender identity and be considered as a third sex."But they still have to go miles to get equal treatment in the society.

\section{REFERENCES}

[1] Agrawal, Beena.Mahesh Dattani's Plays: A New Horizon in Indian Theatre.Book Enclave, 2011.

[2] Dattani, Mahesh.Collected Plays I. Penguin, 2005.

[3] De Beauvoir, Simone. TheSecond Sex. Éditions Gallimard, 1949.

[4] Spivak, Gayatri. Can the Subaltern Speak? Edited by Rosalind C. Morris, Columbia University Press, 2010

[5] The Constitution of India. Article 14-15.

[6] National Legal Service Authority versus Union of India and Other Case. The Supreme Court of India. April 2014.

[7] Woolf, Virginia.A Room of One's Own.Hogarth Press, 1929. 